\title{
ОПТИМАЛЬНИЙ СИНТЕЗ ЗВОРОТНИХ КВАНТОВИХ СУМАТОРІВ 3 ДОПОМОГОЮ ГЕНЕТИЧНИХ АЛГОРИТМІВ
}

\author{
Віталій Дейбук, Іон Грицку \\ Кафедра комп’ютерних систем та мереж, факультет комп'ютерних наук, Чернівецький національний \\ університет ім. Юрія Федьковича, вул. Коцюбинського 2, 58012, Чернівці, Україна, \\ e-mail: v.deibuk@chnu.edu.ua, ion_grytsku@mail.ru
}

\begin{abstract}
Резюме: У роботі запропоновано новий спосіб кодування хромосом у генетичному алгоритмі для моделювання схем зворотних повних однорозрядних суматорів з функиією транзиту у базисі елементів Фредкіна. Отримані з допомогою такого підходу схеми мають кращі параметри затримки та кількості зайвих виходів(входів) порівняно з відомими аналогами, щчо демонструє ефективність та застосовність такого підходу.
\end{abstract}

Ключові слова: генетичні алгоритми, еволючійна електроніка, зворотні суматори, елемент Фредкіна.

\section{OPTIMAL SYNTHESIS OF REVERSIBLE QUANTUM SUMMATORS USING GENETIC ALGORITHM}

\author{
Vitaly Deibuk, Ion Grytsku \\ Computer systems and networks department of Chernivtsi National University, 2 Kotsubyns'kogo str., 58012, \\ Chernivtsi, Ukraine, e-mail v.deibuk@chnu.edu.ua, ion_grytsku@mail.ru
}

\begin{abstract}
The paper suggests a new way of chromosome coding in a genetic algorithm for simulation of reversible onebit full summators with propagate function in Fredkin basis. The circuits obtained with the use of such an approach demonstrate better delay parameters and better number of inputs/outputs compared with the known analogs. It confirms the effectiveness and applicability of the proposed approach.
\end{abstract}

Keywords: genetic algorithm, evolutionary electronics, reversible full adder, Fredkin gate.

\section{1. ВСТУП}

Зростання ступеня інтеграції сучасних мікроелектронних пристроїв, підвищення їх складності веде до того, що питання затримки, розсіяння потужності та розмірів стають чи не найважливішими цілями комп'ютерної схемотехніки. При цьому мільйони вентилів, які виконують логічні операції в комп'ютерах, є незворотними. Тобто, кожного разу виконання логічної операції приводить до втрати або стирання деякої частини вхідної інформації, яка розсіюється у вигляді теплової енергії. Для незворотної логіки кожен біт втраченої інформації випромінює $k T \ln 2$ Дж теплової енергії, де $k$ - постійна Больцмана, $T$ - абсолютна температура [1]. При кімнатних температурах на гігагерцових частотах сучасних процесорів, що містять сотні тисяч транзисторів, розсіювана енергія наближається до кількох Вт, що $\epsilon$ наслідком втрати інформації $\mathrm{i}$ веде до виникнення помилок у розрахунках та зменшення часового ресурсу мікросхем. Вирішення цих проблем лежить у площині використання нових революційних технологій, які спроможні кардинально зменшити як споживану потужність, так і розсіяння теплової енергії в комп'ютерних системах.

Вдалою альтернативою в цьому питанні можна вважати використання зворотної логіки, яка останнім часом досить швидко розвивається $[2,3]$, оскільки знаходить застосування у різноманітних областях, таких як квантовий комп'ютинг, нанотехнології, біоінформатика, оптичний комп'ютинг тощо, де, поряд з іншими, важливою умовою $\epsilon$ екстремально низьке 
розсіяння тепла. Можливість використання зворотних логічних операцій, які не знищують вхідну інформацію, теоретично не веде до розсіяння енергії в системах, що їх реалізують. Зворотними є кола (вентилі), в яких вектор вхідних станів завжди можна відновити з вектора вихідних станів. Розробці цифрових зворотних пристроїв присвячена велика кількість досліджень [2-6], які охоплюють як схемотехнічний, так і фізичний аспекти. Однак на сьогодні проблема знаходження оптимального дизайну таких пристроїв ще не розв'язана 3 практичної точки зору [2].

Операція додавання $\epsilon$ однією 3 базових операцій, а суматори належать до найбільш фундаментальних компонентів довільного цифрового процесора. Схемотехніка зворотних суматорів 3 різним типом перенесення вимагає розробки повних однорозрядних зворотних суматорів [7], які у випадку квантового комп’ютингу мають ряд особливостей. Питання оптимального синтезу зворотних повних однорозрядних суматорів для квантових мереж може бути розв'язане 3 допомогою різних стратегій еволюційної електроніки $[8,9]$.

Генетичні алгоритми належать до адаптивних мета-евристичних алгоритмів пошуку оптимального розв'язку різного роду проблем на основі еволюційної ідеї природної селекції та генетики. Вони використовують інтелектуальний випадковий пошук для вирішення проблеми оптимізації у великих просторах станів за багатьма критеріями. Ідеї використання генетичних алгоритмів до синтезу квантових мереж детально розглянуті в роботі [10] і набули подальшого розвитку. Однак більшість підходів основані на використанні базису квантових примітивів (NOT, CNOT, V, V ${ }^{+}$та ін.), в якому синтезовані деякі комбінаційні зворотні пристрої[9].

У даній роботі запропоновано вдосконалений підхід до синтезу квантових зворотних комбінаційних пристроїв, що грунтується на використанні генетичних алгоритмів. Такий підхід до зворотного логічного синтезу пов'язаний 3 необхідністю врахування кількох додаткових умов, а саме, заборона розгалуження за входом та виходом (теорема про заборону клонування [1]) та заборона обернених зв'язків, тобто подача вихідних сигналів логічних елементів на їх входи. В якості базових елементів при синтезі повного однорозрядного зворотного суматора 3 функцією транзиту використано елемент Фредкіна.

\section{2. ПОВНИЙ ОДНОРОЗРЯДНИЙ ЗВОРОТНИЙ СУМАТОР}

Суматори є одними 3 основних блоків, які входять до складу більшості обчислювальних пристроїв. Описані вище необхідні зміни у логіці квантових обчислень вимагають відповідних змін у реалізації суматорів як на логічному, так i на фізичному рівні. В якості базисних логічних елементів можна вибрати зворотні функціонально повні елементи Тоффолі, Фредкіна, Переса та ін. [1,9], які схемотехнічно добре відпрацьовані на рівні примітивів.

Розглянемо коротко логіку основних зворотних елементів. Двокубітовий елемент Фейнмана (CNOT-вентиль, контрольоване $\mathrm{HE}$ ) може бути описаний виразом:

$$
(A, B) \Rightarrow(P, Q)=(A, A \oplus B) .
$$

Це означає, що вихідний біт $P$ повторює вхідний (контролюючий) біт $A$, а на виході $Q$ формується сигнал $A \oplus B$, де додавання для вхідних бітів виконується за модулем 2 . Очевидно, що при $A=0$ на контрольованому виході $Q=B$, а при $A=1$ на виході $Q=\bar{B}$. Графічне позначення елемента Фейнмана (FG) наведено на Рис. 1.

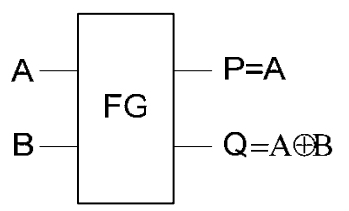

Рис. 1 - Елемент Фейнмана

Трикубітовий елемент Тоффолі (CCNOT двічі контрольоване НЕ), зображений на Рис. 2, виконує функцію:

$$
(A, B, C) \Rightarrow(P, Q, R)=(A, B, A B \oplus C) .
$$

Цей елемент $\epsilon$ універсальним, тобто 3 його допомогою можна отримати довільну логічну функцію, однак він не зберігає парність $(A \oplus B \oplus C$ $\neq P \oplus Q \oplus R)$.

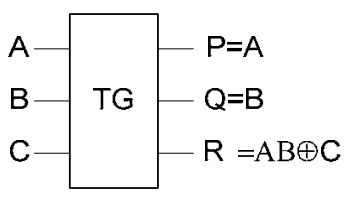

Рис. 2 - Елемент Тоффолі

Трикубітовий зворотний елемент Переса, як видно 3 Рис. 3, поєднує функції елементів Фейнмана і Тоффолі: 


$$
(A, B, C) \Rightarrow(P, Q, R)=(A, A \oplus B, A B \oplus C) .
$$

Хоча він не зберігає парність, однак має найменшу квантову вартість (кількість необхідних для побудови примітивів) серед усіх трикубітових квантових елементів, $\epsilon$ універсальним, а тому знайшов широке використання в комбінаційних зворотних схемах [4]. Зокрема, квантова вартість елемента Фейнмана становить 1 , Переса -4 , елементів Тоффолі та Фредкіна - 5 [9].

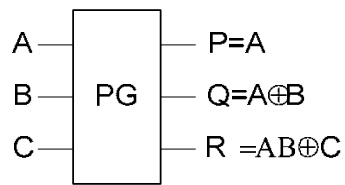

Рис. 3 - Елемент Переса

У роботі [5] нами була проаналізована фізична модель квантового елемента Фредкіна (Рис. 4), який $є$ функціонально повним, зворотним логічним елементом, що зберігає парність, тобто вага за Хеммінгом вхідних сигналів зберігається на виході $(A \oplus B \oplus C=$ $P \oplus Q \oplus R)$.

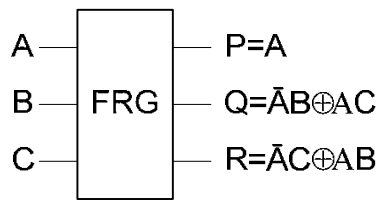

Рис. 4 - Елемент Фредкіна

Трикубітовий елемент Фредкіна (елемент контрольованого обміну) виконує функцію:

$$
(A, B, C) \Rightarrow(P, Q, R)=(A, \bar{A} B \oplus A C, \bar{A} C \oplus A B)
$$

Дослідимо деякі схеми суматорів, побудовані на зворотних логічних елементах $\mathrm{i}$ оцінимо їx ефективність 3 точки зору використання для квантового комп'ютингу. Порівняно 3 класичними схемами у квантових $\epsilon$ ряд обмежень. По-перше, у квантових схемах не допускаються «цикли», тобто зворотний зв'язок від однієї частини квантової схеми до іншої, схема має бути «ациклічною». По-друге, заборонена операція FANIN (можливість 3'єднувати проводи в один, який містить побітове OR входів), яка є незворотною, а, отже, неунітарною. По-третє, у квантових схемах недопустима й обернена операція FANOUT (розгалуження за виходом) через теорему про заборону клонування квантових станів [1]. Важливими $є$ також умови мінімальної кількості зайвих виходів та постійних входів, мінімальної кількості логічних елементів та мінімальної затримки схеми. Для можливості побудови багаторозрядних суматорів необхідно також, крім суми $(S)$ та перенесення $(C)$, передбачити наявність у однорозрядних суматорів виходу транзиту $P=A \oplus B$. Наявність такого виходу дозволяє збудувати багаторозрядні суматори 3 пропущеним перенесенням (CSA), які за швидкодією $€$ компромісним варіантом між паралельними суматорами 3 послідовним (RCA) та прискореним (CLA) перенесенням. Разом 3 тим CSA вигідно відрізняється від двох останніх апаратною складністю, що й зумовлює підвищений інтерес до них, особливо у квантовому комп'ютингу $[3,6,7,11]$. У таких суматорах (CSA) зменшення затримки розрахунку перенесення відбувається за рахунок передачі вхідного перенесення $C_{i-1}$ на вихід $C_{i}$ повного однорозрядного суматора, якщо $P=A \oplus B=1$, тобто, якщо на один 3 входів подано 1.

Абстрагуючись від апаратної частини, побудуємо функціонально-логічні схеми повних однорозрядних суматорів на зворотних логічних елементах Фредкіна, відповідно до наведених вище критеріїв. Такі схеми будуть зберігати парність, оскільки їх базовим елементом $\epsilon$ елемент Фредкіна.

Повний однорозрядний суматор виконує дві функції:

- додавання:

$$
S=A \oplus B \oplus C_{i-1} ;
$$

- формування перенесення в наступний розряд

$$
C_{i}=(A \oplus B) C_{i-1} \vee A B .
$$

На базі елемента Фредкіна можна побудувати різноманітні схеми повного однорозрядного зворотного суматора $[7,11]$. Наведена на Рис. 5 схема синтезована евристичним методом [11] i не містить циклів та розгалужень за виходом елементів, що відповідає описаним вище критеріям до квантових схем і містить вихід транзиту $P$.

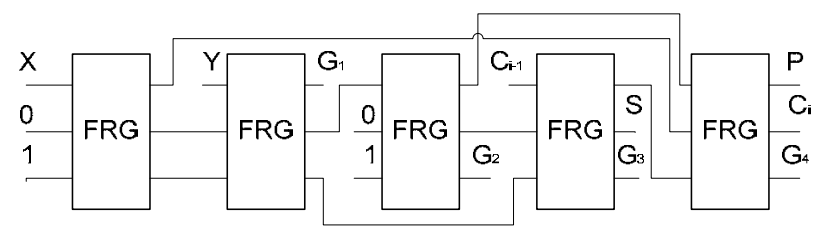

Рис. 5 - Логічна схема повного однорозрядного зворотного суматора 3 функцією транзиту [11] 
Так як квантова ціна вентиля Фредкіна $Q_{c}=5$, то повна квантова вартість всієї схеми (c) рівна кількості примітивів, з яких складається схема. У розглядуваному випадку схема складається виключно $з$ вентилів Фредкіна (FRG), а отже $c=$ $5 n$, де $n$ - кількість вентилів Фредкіна. Схема повного зворотного суматора 3 функцією транзиту $(P)$, зображена на Рис. 5, складається 3 п’яти елементів Фредкіна, має квантову вартість рівну $c=25$, кількість постійних входів -4 , зайвих виходів $\left(G_{i}\right)-4$, затримка такого суматора становить 5 . За вказаними параметрами дана схема на сьогодні вважається кращою. Підійдемо до знаходження оптимального схемотехнічного рішення, використавши еволюційну стратегію пошуку $[8,9]$.

\section{3. ГЕНЕТИЧНИЙ ПОШУК ОПТИМАЛЬНОГО СУМАТОРА}

\section{Кодування та генерування початкової популяції}

Для пошуку оптимального зворотного суматора за наведеними вище критеріями використано генетичний алгоритм. Генетичні алгоритми відрізняються від традиційних оптимізаційних та пошукових процедур тим, що вони працюють 3 кодами параметрів, а не 3 самими параметрами; пошук ведеться за множиною точок, а не за однією точкою; в алгоритмах використовується лише інформація функції пристосованості (цільової функції), а не iii похідних або інша додаткова інформація; використовуються ймовірнісні, а не детерміновані правила переходів. У нашому випадку розв'язком задачі генетичного пошуку $є$ оптимізована комбінаційна схема, тому хромосома повинна представлятись у вигляді певного запису даної схеми.

Оскільки хромосома $є$ набором генів, а схема - певне послідовно-паралельне розташування логічних вентилів Фредкіна, а також інформація про вхідні сигнали, то кожен ген представляє собою один послідовний крок обробки сигналів, що може складатися 3 кількох паралельно розміщених логічних елементів. Таким чином, аналізовані логічні схеми (хромосоми) представимо як набір горизонтальних ліній (пінів), вздовж яких передається інформація і вертикальних секцій, які можуть складатися 3 кількох логічних елементів, в яких відбувається паралельна обробка інформації, i які відповідають генам. При цьому кожен ген кодується у вигляді масиву пар цілих чисел, де перше число в кортежі позначає порядковий номер відповідного логічного елемента в гені, а друге число - порядковий номер піна даного логічного елемента (Рис. 6).

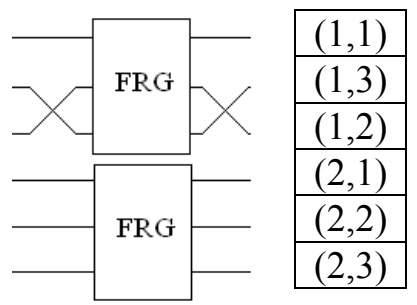

Рис. 6 - Приклад кодування гена

У свою чергу хромосоми, крім наборів зв'язаних між собою генів, складаються також із вектора значень вхідних сигналів. Ці значення записуються в першому елементі хромосоми i також складають окремий ген. Для простоти моделювання комбінаційних схем вважатимемо, що вхідні інформаційні сигнали завжди подаються на верхні лінії, а постійні - на нижні. Приклад представлення хромосоми (схеми) та іiі кодування подано на Рис. 7. Генерація початкової популяції відбувається методом випадкового створення масиву хромосом. При створенні гена випадковим чином визначається кількість логічних елементів в гені, а також спосіб їх розміщення, при цьому враховуються тип вентилів та їх розмір. Таким чином, на початку роботи ми отримуємо набір різних комбінаційних схем (хромосом).

\section{Моделювання схеми}

Знаючи спосіб розміщення елементів у схемі, а також значення постійних входів, робота схеми моделювалася наступним чином. Спочатку генеруються початкові дані (змінні та постійні) і записуються в таблицю значень. Потім почергово подаються початкові значення на вхід гена, а отримані дані подаються як початкові на вхід наступного гена. Це продовжується, поки не змоделюється вся схема. Таким чином, отримаємо таблицю значень вихідних сигналів схеми. Після цього вона поелементно порівнюється 3 таблицею істинності суматора та підраховується кількість значень, що не збігаються (Error).

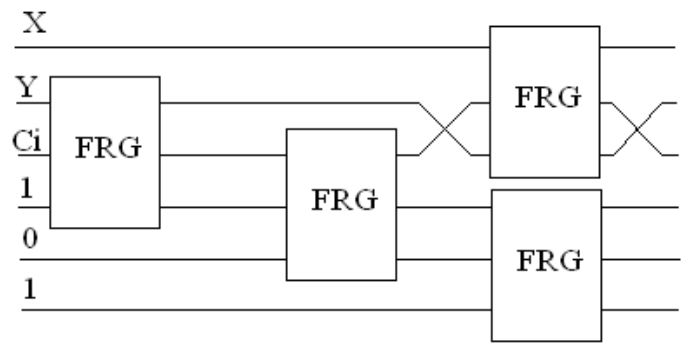

Рис. 7 - Приклад представлення хромосоми 


\section{Функція пристосованості (фітнес-функція)}

Важливою рисою генетичного алгоритму $\epsilon$ вибір функції пристосованості кожної хромосоми. Вона визначає придатність кожної хромосоми 3 точки зору оцінки помилки. У роботі запропонована зважена функція пристосованості наступного вигляду:

$$
f=\alpha\left(\frac{1}{\text { Error }+1}\right)+\beta G(c)+\gamma H\left(g_{i}\right)+\delta I(s),(1)
$$

де Error - кількість помилок у вихідних значеннях модельованої схеми (сума, перенесення та транзит) порівняно зі схемою суматора;

$$
G(c)=\exp \left[-\left(1-\frac{5}{c}\right)^{2}\right]
$$

- функція оцінки квантової вартості (c) схеми;

$$
H\left(g_{i}\right)=\frac{1}{1+g_{i}}
$$

- функція оцінки кількості постійних входів (надлишкових виходів) $\left(g_{i}\right)$;

$$
I(s)=\exp \left[-\left(1-\frac{1}{s}\right)^{2}\right]
$$

- функція оцінки затримки схеми $(s)$

Вагові коефіцієнти $\alpha, \beta, \gamma, \delta$ задовольняють умову

$$
\alpha+\beta+\gamma+\delta=1 \text {. }
$$

Пошук оптимальної за вказаними параметрами схеми пов'язаний зі знаходженням максимального значення функції пристосованості $f$. Мінімальна кількість постійних входів шуканої схеми забезпечить мінімальну кількість надлишкових виходів. Величина затримки $(s)$ схеми оцінювалась у відносних одиницях часу затримки одного логічного елемента.

\section{Селекція, схрещування та мутація}

У роботі використовувались турнірна селекція та двоточкове схрещування, що відбувається наступним чином. Випадково вибираються дві п'ятірки хромосом, порівнюються їх функції пристосованості в межах кожної п'ятірки і вибираються по одній найкращій хромосомі. Ці дві особини

\begin{tabular}{|c|c|c|c|}
\hline $\begin{array}{c}\text { Вхідні } \\
\text { знач. }\end{array}$ & Ген1 & Ген2 & Ген3 \\
\hline$X$ & $(0,0)$ & $(0,0)$ & $(1,1)$ \\
\hline $\mathrm{Y}$ & $(1,1)$ & $(0,0)$ & $(1,3)$ \\
\hline $\mathrm{C}_{\mathrm{i}}$ & $(1,2)$ & $(1,1)$ & $(1,2)$ \\
\hline 1 & $(1,3)$ & $(1,2)$ & $(2,1)$ \\
\hline 0 & $(0,0)$ & $(1,3)$ & $(2,2)$ \\
\hline 1 & $(0,0)$ & $(0,0)$ & $(2,3)$ \\
\hline
\end{tabular}
відбираються в батьківську популяцію. Після цього 3 імовірністю 0,8 відбувається схрещування батьківських хромосом: випадковим чином вибираються дві алелі (але не рівні між собою) і батьківські хромосоми обмінюються між собою відповідними генами, що знаходяться між цими алелями. Отриманий результат записується в популяцію-нащадок. Мутація здійснюється 3 імовірністю 0,02 наступним чином: $\mathrm{y}$ певній хромосомі вибирається випадковим чином ген і замінюється новоствореним випадкового вигляду.

\section{Завершення алгоритму}

У випадку, якщо функція пристосованості деякої хромосоми стане максимально близькою до одиниці, це означатиме, що вона досягла свого максимуму і ми отримали шукану схему. Максимальна кількість ітерацій обмежується.

\section{4. РЕЗУЛЬТАТИ ТА ОБГОВОРЕННЯ}

Алгоритм було використано для синтезу повного однорозрядного зворотного суматора в базисі елементів Фредкіна (таблиці 1-4). Для описаного генетичного алгоритму було використано наступні параметри:

ймовірність схрещування $-0,8$;

ймовірність мутації - 0,02 ;

кількість хромосом в популяцій - 100;

кількість генів у хромосомі - 10;

розмірність гена -7 ;

максимальна кількість поколінь - 3000.

Оскільки ваговий коефіцієнт $\alpha$ визначає внесок функції помилок у загальну фітнесфункцію (1), то для коректної роботи алгоритму (отримання схеми суматора) було прийнято $\alpha \geq$ 0,8. Залежно від параметрів, за якими потрібно здійснювати оптимізацію схеми суматора, відповідні коефіцієнти $\beta, \delta, \gamma$ змінювалися при обов'язковому дотриманні умови (5). При багатопараметричній оптимізації одночасно за всіма параметрами вагові коефіцієнти вибиралися 3 умови $\beta=\delta=\gamma=(1-\alpha) / 3$. В середньому, для отримання шуканої хромосоми було використано порядку 200 поколінь.

У таблиці 1 наведено результати моделювання повного однорозрядного зворотного суматора, оптимізованого за кількістю постійних входів $\left(g_{i}\right)$. За наведеною вихідною хромосомою побудовано логічну 
схему, параметри якої $-c=25 ; g_{i}=2 ; s=5$. Врахування умови наявності у схемі суматора функції транзиту (Р) дозволило отримати схему, яка повністю співпала 3 синтезованою в роботі [11]. Отримана схема та відповідна їй хромосома подані в таблиці 2 ( $\left.c=25 ; g_{i}=4 ; s=5\right)$. Повний однорозрядний зворотний суматор 3 функцією транзиту, оптимізований за часом затримки $(s)$, та відповідна хромосома (таблиця 3) порівняно 3 попередньою схемою має в 1,66 рази менший час затримки при тій же апаратній складності і тій же кількості постійних входів та зайвих виходів $\left(c=25 ; g_{i}=4 ; s=3\right)$. Моделювання суматора 3 функцісю транзиту при оптимізації за кількістю постійних входів та зайвих виходів $\left(g_{i}\right)$ дозволило отримати схему і відповідну ій хромосому, наведені у таблиці $4\left(c=25 ; g_{i}=3 ; s\right.$ $=4)$. Хоча затримка останньої схеми перевищує затримку попередньої схеми, однак кількість зайвих виходів вдалося зменшити до 3 , що у квантовому комп'ютингу $є$ доволі важливо. Останні дві схеми зворотних суматорів 3 функцією транзиту отримані нами вперше i порівняно з відомими аналогами [3,6,7,11] при тій же апаратній складності мають кращі параметри як за часом затримки $(s=3)$, так і за кількістю зайвих виходів (постійних входів) $g_{i}=3$.

На Рис. 8 наведено графік залежності максимального значення фітнес-функції від номера покоління.

Таблиця 1. Повний однорозрядний зворотний суматор, оптимізований за кількістю постійних входів $\left(c=25 ; g_{i}=2 ; s=5\right)$

\begin{tabular}{|c|c|c|c|c|c|c|c|c|}
\hline \multicolumn{7}{|c|}{ Отримана хромосома } & \multicolumn{5}{c|}{ Відповідна комбінаційна схема } \\
\hline $\mathrm{X}$ & $(1,1)$ & $(1,1)$ & $(0,0)$ & $(1,3)$ & $(1,2)$ & $\mathrm{S}$ \\
\hline $\mathrm{Y}$ & $(1,3)$ & $(0,0)$ & $(1,3)$ & $(1,2)$ & $(1,3)$ & $\mathrm{C}_{\mathrm{i}}$ \\
\hline $\mathrm{C}_{\mathrm{i}-1}$ & $(0,0)$ & $(0,0)$ & $(1,1)$ & $(0,0)$ & $(1,1)$ & $\mathrm{G}_{3}$ \\
\hline 1 & $(0,0)$ & $(1,3)$ & $(1,2)$ & $(1,1)$ & $(0,0)$ & $\mathrm{G}_{2}$ \\
\hline 0 & $(1,2)$ & $(1,2)$ & $(0,0)$ & $(0,0)$ & $(0,0)$ & $\mathrm{G}_{1}$ \\
\hline
\end{tabular}

Таблиця 2. Повний однорозрядний зворотний суматор 3 функцісю транзиту $(\mathrm{P})\left(c=25 ; g_{i}=4 ; s=5\right)$

\begin{tabular}{|c|c|c|c|c|c|c|c|}
\hline \multicolumn{7}{|c|}{ Отримана хромосома } & \multicolumn{3}{c|}{ Відповідна комбінаційна схема } \\
\hline $\mathrm{X}$ & $(1,1)$ & $(0,0)$ & $(0,0)$ & $(0,0)$ & $(1,2)$ & $\mathrm{C}_{\mathrm{i}}$ \\
\hline $\mathrm{Y}$ & $(0,0)$ & $(1,1)$ & $(0,0)$ & $(0,0)$ & $(0,0)$ & $\mathrm{G}_{1}$ \\
\hline $\mathrm{C}_{\mathrm{i}-1}$ & $(0,0)$ & $(0,0)$ & $(0,0)$ & $(1,1)$ & $(1,3)$ & $\mathrm{G}_{4}$ \\
\hline 0 & $(1,2)$ & $(1,2)$ & $(1,1)$ & $(0,0)$ & $(1,1)$ & $\mathrm{P}$ \\
\hline 1 & $(1,3)$ & $(1,3)$ & $(0,0)$ & $(1,3)$ & $(0,0)$ & $\mathrm{G}_{3}$ \\
\hline 0 & $(0,0)$ & $(0,0)$ & $(1,2)$ & $(1,2)$ & $(0,0)$ & $\mathrm{S}$ \\
\hline 1 & $(0,0)$ & $(0,0)$ & $(1,3)$ & $(0,0)$ & $(0,0)$ & $\mathrm{G}_{2}$ \\
\hline
\end{tabular}

Таблиця 3. Повний однорозрядний зворотний суматор з функцією транзиту(Р), оптимізований за часом затримки $\left(c=25 ; g_{i}=4 ; s=3\right)$

\begin{tabular}{|c|c|c|c|c|c|c|}
\hline \multicolumn{5}{|c|}{ Отримана хромосома } & \multicolumn{2}{c|}{ Відповідна комбінаційна схема } \\
\hline $\mathrm{X}$ & $(1,1)$ & $(2,2)$ & $(2,1)$ & $\mathrm{P}$ & \\
\hline $\mathrm{Y}$ & $(0,0)$ & $(2,1)$ & $(0,0)$ & $\mathrm{G}_{1}$ & \\
\hline $\mathrm{C}_{\mathrm{i}-1}$ & $(0,0)$ & $(1,1)$ & $(2,3)$ & $\mathrm{G}_{4}$ & \\
\hline 1 & $(0,0)$ & $(1,3)$ & $(1,3)$ & $\mathrm{S}$ & \\
\hline 1 & $(1,3)$ & $(2,3)$ & $(1,1)$ & $\mathrm{G}_{2}$ & \\
\hline 0 & $(1,2)$ & $(0,0)$ & $(2,2)$ & $\mathrm{C}_{\mathrm{i}}$ \\
\hline 0 & $(0,0)$ & $(1,2)$ & $(1,2)$ & $\mathrm{G}_{3}$ & \\
\hline
\end{tabular}


Таблиця 4. Повний однорозрядний зворотний суматор з функцісю транзиту(Р), оптимізований за кількістю постійних входів та надлишкових виходів $\left(c=25 ; g_{i}=3 ; s=4\right)$

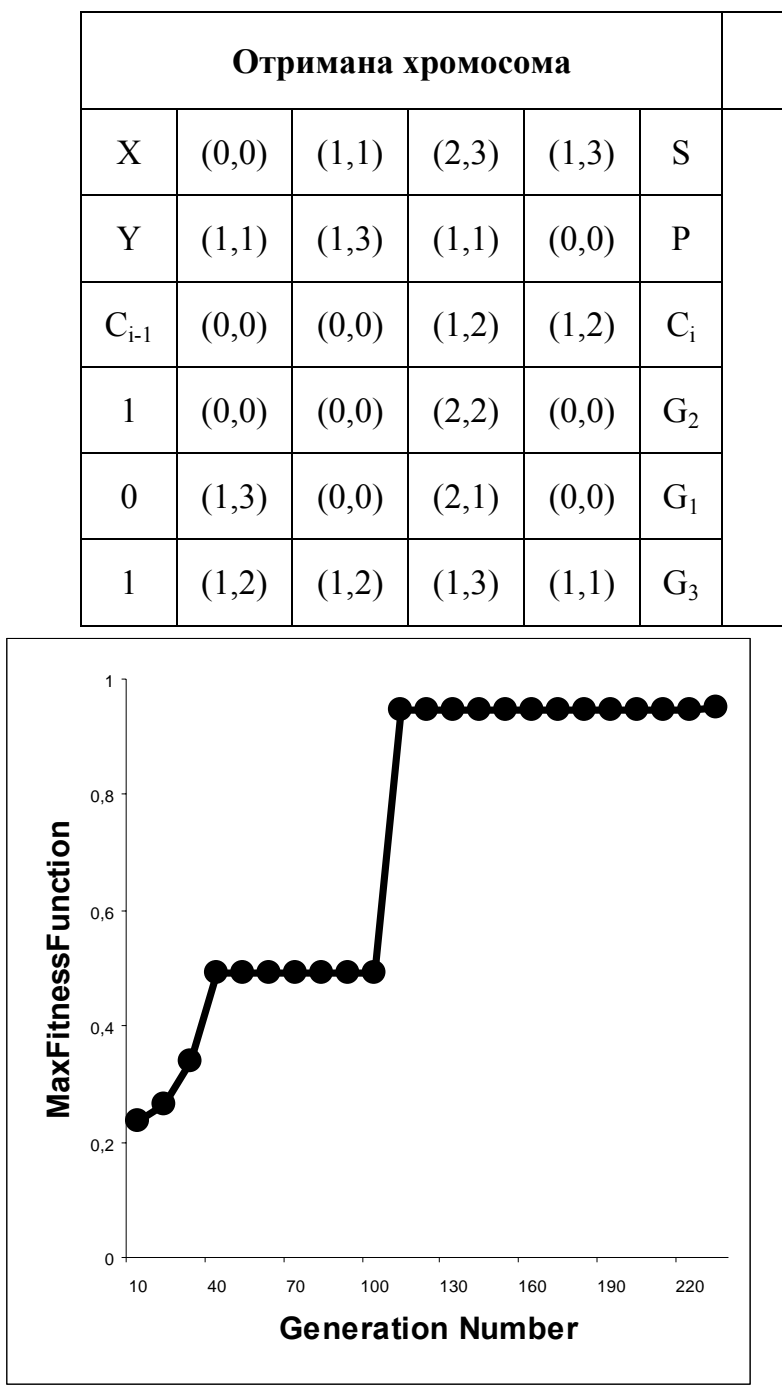

Рис. 8 - Залежність максимального значення фітнес-функції від номера покоління

\section{5. ВИСНОВКИ}

$\mathrm{У}$ роботі запропоновано новий спосіб кодування хромосом у генетичному алгоритмі для моделювання схем зворотних повних однорозрядних суматорів 3 функцією транзиту у базисі елементів Фредкіна. Отримані 3 допомогою такого підходу схеми мають кращі параметри затримки та кількості зайвих виходів(входів) порівняно з відомими аналогами, що демонструє ефективність та застосовність такого підходу.

\section{6. СПИСОК ЛІТЕРАТУРИ}

[1] M.A. Nielsen, I.L. Chuang, Quantum computation and quantum information. Cambridge University Press, NY, 2001, p. 676.

[2] P. Kerntopf, M. Perkowski, K. Podlaski, Synthesis of reversible circuits: A view on the state-of-the-art, 12 International Conference on
Відповідна комбінаційна схема

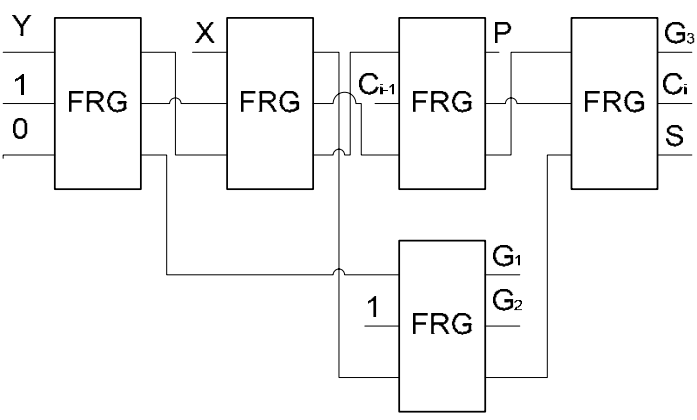

Nanotechnology, Birmingham, UK (20-23 August 2012), pp. 1-6.

[3] Santanu Maity, Bishnu Prasad De, Aditya Kr. Singh, Design and implementation of lowpower high-performance carry skip adder, Int. $J$. of Engineering and Advanced Technology, (1) 4 (2012), pp. 212-218.

[4] V. G. Deibuk. I.M. Yuriychuk, R.I. Yuriychuk, Spin model of full summator on Peres gates, Int. J. Computing, (11) 3 (2012), pp. 282-292 (in Ukrainian).

[5] G. P. Gorskyi, V. G. Deibuk, Four spins model of universal quantum Fredkin gate, Informational technologies and computer engineering, (2) 21 (2011), pp. 56-63 (in Ukrainian).

[6] S. Islam, R. Islam, Minimization of reversible adder circuits, Asian J. of Information Technology, (4) 12 (2005), pp. 1146-1151.

[7] P.K. Lala, J.P. Parkerson, P. Chakraborty, Adder designs using reversible logic gates, WSEAS Transactions on Circuits and Systems, (9) 6 (2010), pp. 369-378.

[8] R.S. Zebulum, M.C. Pachecco, M.M. Vellasco, Evolutionary Electronics: Automatic Design of Electronic Circuits and Systems by Genetic Algorithms, CRC Press, 2002, p. 304.

[9] M. Lukac, M. Perkowski et al., Evolutionary approach to quantum and reversible circuits synthesis, Artificial Intelligence Review, (20) 34 (2003), pp. 361-417.

[10] L. Spector, Automatic Quantum Computer Programming: A Genetic Programming Approach, Kluwer Academic Publishers, 2004, p. 153.

[11] J.W. Bruce, M.A.Tornton et al., Efficient Adder Circuits Based on the Conservative Reversible Logic Gates, Proc. IEEE Comp. Soc. Ann. Symp. on VLSI, Pittsburgh, PA (April 25-26, 2002), pp. 83-88. 


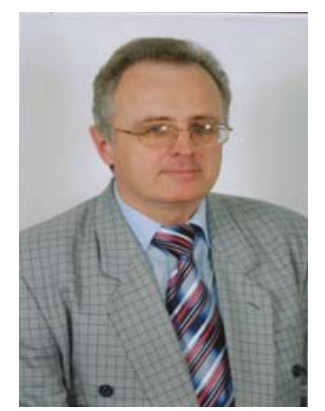

Віталій Дейбук, професор, доктор фрізико-математичних наук, прооресор кафредри “Комп'ютерні системи та мережі" Чернівецького національного універcuтету ім. Юрія Федьковича. Стаж науково-педагогічної діяльності у вищій школі 30 років. Автор понад 150 наукових та науково-методичних праць, в тому числі 3 навчальних посібники 3 грифом Міністерства освіти та науки України.

Наукові інтереси - комп'ютерне моделювання фрізичних властивостей конденсованих систем, проблеми квантової інформатики, дослідження властивостей матеріалів для квантових комп'ютерів

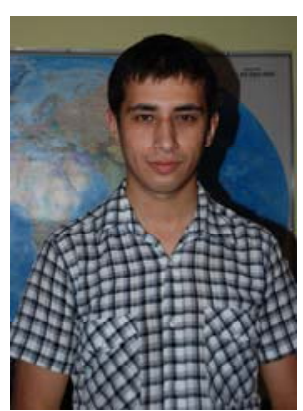

Іон Грицку, магістр комп'ютерних системи та мереж, фрахівець кафредри системи та мереж Чернівецького національного університету імені Юрія Федьковича. Наукові інтереси комп'ютерна схемотехніка, квантовий комп'ютинг, нейронні мережі. 


\title{
OPTIMAL SYNTHESIS OF REVERSIBLE QUANTUM SUMMATORS USING GENETIC ALGORITHM
}

\author{
Vitaly Deibuk, Ion Grytsku \\ Computer systems and networks department of Chernivtsi National University, 2 Kotsubyns'kogo str., 58012, \\ Chernivtsi, Ukraine, e-mail v.deibuk@chnu.edu.ua, ion_grytsku@mail.ru
}

\begin{abstract}
The paper suggests a new way of chromosome coding in a genetic algorithm for simulation of reversible onebit full summators with propagate function in Fredkin basis. The circuits obtained with the use of such an approach demonstrate better delay parameters and better number of inputs/outputs compared with the known analogs. It confirms the effectiveness and applicability of the proposed approach.
\end{abstract}

Keywords: genetic algorithm, evolutionary electronics, reversible full adder, Fredkin gate.

\section{INTRODUCTION}

Increase of integration in modern microelectronic devices along with their complexity enhancement makes the issues of delay, power dissipation and scale the most important goals of computer design. For irreversible logic computations every bit of lost information generates $k T \ln 2 \mathrm{~J}$ of heat energy, where $k-$ Boltzmann constant, $T$ - absolute temperature [1].

Successful alternative with this respect can be the use of reversible logic $[2,3]$. Reversible circuits (gates) are those in which input vector states can always be restored from the output state vector. However, today the problem of finding the optimal design of such devices has not been solved from a practical point of view [2]. Adders are among the most fundamental components of any digital processor.

This paper presents an improved approach to the synthesis of combinational quantum reversible devices, based on the use of genetic algorithms. Such an approach to the reversible logic synthesis is associated with the need to consider several additional conditions, namely, the prohibition of branching for input and output (non-cloning theorem [1]) and the suppression of inverse relations, i.e. logic elements output signals supply on their inputs . As a basic element in the synthesis the full adder with propagate Fredkin gate was used.

\section{OPTIMAL SCHEME GENETIC SEARCH}

Since the chromosome is a set of genes, and the circuit is some series-parallel arrangement of logic Fredkin gates, let's consider the chromosome representation as a set of horizontal lines (pins), along which information is transmitted and vertical sections, which may consist of several logical elements, implementing information parallel processing, and correspond to genes. While each gene is encoded as an array of pairs of integers, where the first number is the number of logical gate in the gene, and the second number is the index of pin in the given logic element (Fig. 6). In turn chromosomes, except interconnected sets of genes, include a vector of values of the input signals. These values are stored in the first element of the chromosome and also form a separate gene (Fig. 7). The paper proposes a balanced fitness function of the following form:

$$
f=\alpha\left(\frac{1}{\text { Error }+1}\right)+\beta G(c)+\gamma H\left(g_{i}\right)+\delta I(s),
$$

where Error - number of errors in the initial values of the simulated circuit (sum, carry or propagate), compared with the adder circuit;

$$
G(c)=\exp \left[-\left(1-\frac{5}{c}\right)^{2}\right]
$$

- evaluation function of quantum cost (c) of the circuit; 


$$
H\left(g_{i}\right)=\frac{1}{1+g_{i}}
$$

- evaluation function of constant inputs (garbage outputs) $\left(g_{i}\right)$;

$$
I(s)=\exp \left[-\left(1-\frac{1}{s}\right)^{2}\right]
$$

- evaluation function of circuits delay (s).

Weights $\alpha, \beta, \gamma, \delta$ satisfy the condition

$$
\alpha+\beta+\gamma+\delta=1 \text {. }
$$

Finding the optimal circuit in accordance with specified parameters is associated with finding the maximum value of fitness function $f$. Minimum constant inputs in the desired circuit will provide the minimum number of garbage outputs.

Latency (s) of circuit was estimated in relative units of delay time of one logic element. We used tournament selection and two-point crossover.

\section{RESULTS AND DISCUSSION}

The genetic algorithm has been used for the synthesis of reversible full adder based on Fredkin gates (Table 1-4). For the described genetic algorithm the following parameters were used:

probability of crossover -0.8 ;

probability of mutation -0.02 ;

number of chromosomes in the population - 100;

number of genes in the chromosome - 10;

gene dimension -7 ;

maximum number of generations -3000 .

Since the $\alpha$ weighting factor determines the contribution of errors function in general fitness function (1), for the correct algorithm operation (an adder circuit) $\alpha \geq 0,8$ was taken. Depending on the parameters needed to optimize the adder circuit, the corresponding coefficients of $\beta, \gamma, \delta$ were changed while the (5) condition was met. In multiparameter optimization for all parameters simultaneously weights were chosen from the condition $\beta=\delta=\gamma=$ $(1-\alpha) / 3$. On average, to get a needed chromosome it took about 200 generations.

Table 1 shows the results of the simulation reversible full adder optimized for the number of garbage outputs $\left(g_{i}\right)$. For given initial chromosome a logic circuit with parameters of $c=25 ; g_{i}=2 ; s=5$ was constructed. Considering the propagate function $(P)$ is present in the circuit adder, we may obtain a circuit, which completely coincides with the one synthesized in [4]. The circuit and the corresponding chromosome are given in Table $2\left(c=25 ; g_{i}=4 ; s=\right.$
5). Reversible full adder with propagate function, optimized for delay time (s). The corresponding chromosome (Table 3) demonstrates 1.66 lower delay time in comparison with the previous circuits for the similar hardware complexity and the same number of constant inputs and garbage outputs $(c=$ 25; $g_{i}=4 ; s=3$ ). Simulation of the full adder with propagate optimized by the number of constant inputs and garbage outputs $\left(g_{i}\right)$ allowed to obtain the circuit and the corresponding chromosome, shown in Table $4\left(c=25 ; g_{i}=3 ; s=4\right)$. The last circuit delay exceeds the previous circuit delay, whereas the number of garbage outputs was reduced to 3 . The last two circuits of reversible adders with propagate received by us for the first time and compared with known analogues $[3,4]$ with the same hardware complexity possess better parameter both of delay (s $=3$ ) and the number of garbage outputs (constant inputs) $g_{i}=3$. Fig. 8 shows a dependency of the maximum value of the fitness function versus the number of generations.

\section{CONCLUSIONS}

The paper suggests a new way of chromosome coding in genetic algorithm for simulation of reversible full adder with propagate based on Fredkin gates. The circuits obtained with the use of such an approach demonstrate better delay parameters and the number of garbage outputs compared to the known analogs, pointing out the effectiveness and applicability of the approach proposed.

\section{REFERENCES}

[1] M.A. Nielsen, I.L. Chuang, Quantum computation and quantum information. Cambridge University Press, NY, 2001, p. 676.

[2] P. Kerntopf, M. Perkowski, K. Podlaski, Synthesis of reversible circuits: A view on the state-of-the-art, 12 International Conference on Nanotechnology, Birmingham, UK (20-23 August 2012), pp. 1-6.

[3] Santanu Maity, Bishnu Prasad De, Aditya Kr. Singh, Design and implementation of lowpower high-performance carry skip adder, Int. J. of Engineering and Advanced Technology, (1) 4 (2012), pp. 212-218.

[4] J.W. Bruce, M.A. Tornton et al., Efficient Adder Circuits Based on the Conservative Reversible Logic Gates, Proc. IEEE Comp. Soc. Ann. Symp. on VLSI, Pittsburgh, PA (April 25-26, 2002), pp. 83-88. 